\title{
IMPLEMENTASI MEDIA ANIMASI KOMPUTER DALAM PEMBELAJARAN SISTEM PEREDARAN DARAH MANUSIA PADA SMP ABT KOTA SORONG
}

\section{JULIA.F.TUHUMURY}

\author{
SMP ABT Kota Sorong
}

Email: raniyulia34@gmail.com.

\begin{abstract}
ABSTRAK
Pembelajaran dengan menggunakan media animasi komputer memberikan kesempatan kepada perserta didik untuk belajar secara dinamis dan interaktif. Penelitian ini bertujuan untuk mengetahui efektifitas dari penggunaan media animasi komputer dalam pembelajaran pada siswa SMP ABT Kota Sorong. Penelitian ini dilakukan di SMP ABT Kota Sorong dengan mengunakan populasi seluruh siswa SMP ABT Kota Sorong dan sampelnya siswa kelas VIII SMP ABT Kota Sorong yaitu kelas VIIIA sebagai kelas eksperimen sebanyak 24 siswa, dan kelas VIIIB sebagai kelas kontrol sebanyak 24 siswa selama satu bulan. Metode penelitian yang dilakukan adalah eksperimen.Teknik pengambilan Sampel pada penelitian ini secara purposive sampling. Uji validitas dan realibilitas berdasarkan penelitian para ahli. Instrumen penelitian yang digunakan adalah instrument tes hasil belajar,angket,dan observasi. Data penelitian ini di peroleh berupa data kualitatif yang di ubah kuantitatif kemudiaan dianalisa dengan menggunakan SPSS 20. Instrumen yang digunakan adalah tes tertulis dan angket. Hasil belajar kelas kontrol terhadap kelas eksperimen, 3,761 > 2,04841, sehingga H0 ditolak H1 diterima, ini berarti hasil belajar kelas eksperimen lebih baik. Hasil angket antara kelas kontrol terhadap kelas eksperimen masing-masing 2,456 > 2,0484. Maka Ho ditolak H1 diterima,ini berarti motivasi siswa kelas eksperimen lebih baik. Secara keseluruhan penerapan media animasi komputer efektif pada ranah kognitif, afektif dalam pembelajaran peredaran darah manusia di SMP ABT Kota Sorong.
\end{abstract}

Kata kunci: Implementasi, efektivitas, media, animasi, komputer

\section{ABSTRACT}

Learning by using computer animation media provides the opportunity for learners to learn in a dynamic and interactive way. This research aims to determine the effectiveness of the using of computer animation in the media on student learning SMP ABT Sorong. This research was conducted in SMP ABT Sorong by using all students at SMP ABT as population and taking students of eighth grade students as sample, they were students of class VIIIA as an experimental class with 24 students, and the class VIIIB as control class with 24 students for one month. Research methodology was experiment. The samples were taken by using purposive sampling. Validity and reliability test based on research experts. The research instruments that had been used in this rsearch was the achievement test, questionnaire, and observation. The research data was obtained in the form of qualitative data then changed to quantitative form and analyzed by using SPSS 20. The instruments used were written tests and questionnaires. The results study of the control class toward experimental class, 3.761> 2.04841, so that H0 rejected $\mathrm{H} 1$ accepted, this means learning result of experimental class better. The questionnaire results between the control class against class experiment respectively 2,456> 2.0484. Then Ho was rejected but H1 was accepted, this mean that the motivation of students in the experiment class was better. The implementation of computer animation was effective on cognitive and affective in the learning of human circulatory at SMP ABT Sorong.

Keywords: Implementation, effectiveness, computer, animation, media

\section{PENDAHULUAN}

Pendidikan adalah usaha sadar dan terencana untuk mewujudkan suasana belajar dan proses pembelajaran agar peserta didik secara aktif mengembangkan potensi dirinya untuk memiliki kekuatan ,keagamaan, pengendalian diri, masyarakat, bangsa dan Negara (1). Pendidikan nasional berfungsi mengembangkan kemampuan dan membentuk watak serta peradaban bangsa yang bermartabat dalam rangka mencerdaskan kehidupan bangsa, bertujuan untuk berkembangnya potensi peserta didik agar menjadi manusia yang beriman dan bertakwa kepada Tuhan yang Masa Esa, berakhlak mulia, sehat, berilmu, cakap, kreatif, mandiri, menjadi warga Negara yang demokratis, dan bertanggung jawab.”(1). Pendidikan di Indonesia sangat memperhatikan,hal tersebut tercernin dari hasil studi yang dilakukan oleh organisasi studi Institut Education Achievement (IEA) menunjukan bahwa kemampuan siswa SLTP (Sekolah Lanjutan Tingkat Pertama) untuk IPA berada pada urutan ke 40 dan ke 42 negara peserta (2) SLTP adalah pendidikan formal di Indonesia, merupakan jenjang pendidikan menengah setelah menamatkan sekolah dasar atau sederajat.kualitas. Mata pelajaran di SLTP yakni salah satunya adalah Ilmu pengetahuan alam (IPA). Ilmu pengetahuan alam (IPA) adalah pengetahuan rasional 
dan objektif tentang alam dan isinya. Pembelajaran Sains berupaya meningkatkan minat belajar siswa agar mau meningkatkan pemahanan dan kecerdasan serta memupukan rasa ingin tahu yang tinggi secara alamiah (3)

Pada umumunya di sekolah dasar maupun sekolah menengah, pelajaran IPA merupakan salah satu pelajaran yang tidak disukai oleh peserta didik selain pelajaran Matematika sehingga menurunnnya minat belajar dikalangan peserta didik, dan berakibat pada tidak mencukupi nilai Kriteria Ketuntasan Minimal (KKM), selain itu ada beberapa permasalahan pembelajaran IPA dilapangan seperti: 1) Dalam proses belajar mengajar, guru tidak memberikan siswa untuk mengembangkan kreatifitas, hal ini karena gaya guru yang mengajar mendril siswa untuk menghapal konsep tanpa disertai pemahaman konsep tersebut. 2). Ketrampilan proses belum nampak di sekolah karena masih mengejar target kurikulum (3)

Seiring pesatnya perkembangan ilmu pengetahuan dan teknologi telah memberikan solusi bagi setiap guru untuk berupaya meningkatakan kualitas pembelajaran IPA, dengan mengembangkan metode dan media pembelajaran yang akan diterapkan, saat pelaksananan kegiatan pembelajaran di kelas. Media pembelajaran merupakan salah satu penentu keberhasilan pembelajaran, melalui media ini proses pembelajaran bisa lebih menarik dan menyenangkan. Teknologi komputer bukan hanya untuk orang dewasa saja, akan tetapi bagi peserta didik yang duduk dijenjang pendidikan dasar juga layak, untuk diperkenalkan dengan komputer (4).

Beberapa media pembelajaran yang pernah diberlakukan dan diteliti yakni Macromedia Flash 8 (5), Media Audio Visual (6), multi media (7), jelajah alam sekitar (8) Sebagai upaya menanggulangi masalah dalam pembelajaran. Pengunaan media animasi komputer menjadi salah satu cara yang digunakan untuk mempermudah siswa dalam memahami materi yang disampaikan.

Akan tetapi, pada sekolah SMP ABT kota Sorong jarang mengunakan media animasi komputer dalam proses pembelajaran sehingga berdampak pada motivasi siswa dan hasil belajar yang rendah. Maka perlu dilakukan pembelajaran IPA (Biologi) dengan mengunakan media animasi komputer. Namun pengunaan media animasi komputer juga masih perlu dilakukan penelitian untuk mengetahui dampak atau keefktifan dari media tersebut dalam proses pembelajaran. Tujuan penelitian ini adalah untuk mengetahui efektifitas dari penggunaan media animasi komputer dalam pembelajaran pada siswa SMP ABT Kota Sorong.

\section{METODE PENELITIAN}

Penelitian ini merupakan penelitian eksperimen quasi (9). Penelitian ini dikaji dengan metode kuantitatif dan kualitatif. (10).

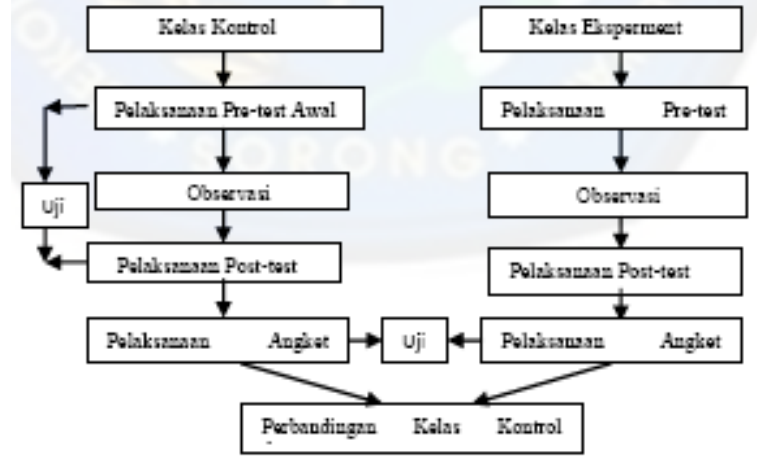

Gambar. 2.1 Alur Penelitian

Populasi penelitian ini adalah seluruh siswa SMP ABT Kota Sorong sebanyak 48 siswa (11). Sampel dalam penelitian ini adalah siswa SMP ABT Kota Sorong Kelas VIIIA dan kelas VIIIB tahun akademik 2014/2015 masing-masing sebanyak 24 siswa dan 24 siswa (12). Cara pengambilan sampel

di lakukan pengambilan menurut tujuan (Purposive sampling).

Identifikasi variable penelitian yang direncanakan adalah tentang penerapan media animasi komputer terhadap pembelajaran materi sistem peredaran darah pada manusia. Variable tetap pada penelitian ini adalah materi sistem peredaraan darah pada manusia. Variabel bebas pada penelitian ini adalah penerapan media animasi komputer.

Materi penelitian ini adalah animasi komputer untuk bahan ajar sistem peredaraan darah manusia

Alat atau Instrumen Pengambilan Data

Jenis instrumen penelitian yang akan digunakan adalah tes tertulis, angket, observasi kegiatan siswa, observasi proses belajar mengajar dan dokumentasi (13).

Uji instrumen pada penelitian ini akan dilakukan dengan menggunakan perhitungan validitas instrumen dan reliabilitas instrumen.

Penelitian ini dilaksanakan di Sekolah SMP ABT Kota Sorong, yang beralamat di jalan Nusa Indah Kelurahan Klademak Distrik Sorong Kota. Waktu penelitian ini diperkirakan selama 1 bulan.

Teknik Analisa Data

Adapun langkah - langkah yang ditempuh dalam pengolahan data adalah sebagai berikut : Uji Prasyarat, Uji Homogenitas, Uji Normalitas, Uji Kesukaran Soal, Uji Relabilitas

\section{PEMBAHASAN}

Data - data yang dihasilkan penelitian ini dilakukan analisis dengan menggunakan beberapa perhitungan statistik. Perhitungan statistik yang dilakukan menggunakan aplikasi komputasi yakni aplikasi Anastesis dan SPSS 20 . Beberapa data dalam penelitian ini tidak dilalakukan analisis dengan menggunakan perumusan statistik yakni data observsi dan data dokumentasi. Data- data tersebut hanya bertindak sebagai data pendukung penelitian atau pendukung data - data lain yang dilakukan analisis. Hal ini disebabkan karena data tersebut secara statistik tidak 
dapat dilakukan perhitungan.

Instrumen yang digunakan dalam penelitian ini dianalisis guna mengetahui kelayakan sebagai instrument penelitian. Hasil analisis masing - masing instrumen diuji untuk memenuhi asumsi landasan teori yang mendasar

Instrument tes tertulis awal sebelum diberlakukan ke siswa yang dijadikan sampel maka dilakukan uji daya pembeda. Uji dilakukan kepada 15 orang siswa dari kelas yang tidak digunakan sebagai sampel penelitian.

Hasil analisis menunjukan bahwa nilai daya pembeda soal ( t DP \%) yakni antara 25.00 sampai dengan 100.00. Hasil ini berarti butir soal no $1,7,10$ memilki daya pembeda jelek. Nilai pembeda butir soal no 9,4,6 nilainya cukup. Dan nilai pembeda butir soal no 2,5 nilainya baik.

Uji Tingkat Kesukaran Soal Tes Tertulis

Instrumen tes tertulis awal sebelum dilakukan ke siswa yang dijadikan sampel maka dilakukan uji tingkat kesukaran. Uji dilakukan kepada 15 orang siswa dari kelas yang tidak digunakan untuk sampel penelitian.

Hasil analisa menunjukan bahwa dari sepuluh soal yang disusun diperoleh tingkat kesukaran soal dengan tafsiran soal yang sedang, sukar dan sangat sukar. Berdasarkan hasil uji butir soal nomor 8 sangat sukar dan tidak layak digunakan untuk instrument penelitian.

Data hasil uji instrument yang diberlakukan kepada 15 siswa diluar kelas sampel diuji reliabilitas soal guna mengetahui tingkat reliabel uji reliabilitas diperoleh seperti input berikut ini:

Hasil menunjukan bahwa nilai reliabilitas yakni $\mathrm{r}$ hitung $=1,478>\mathrm{r}$ table sebesar 0,6319 untuk nilai 0.05 maka butir soal tes dinyatakan reliabel.ini menunjukan tingkat reliable diperoleh sangat tinggi.

Hasil perhitunngan validitas untuk masing masing butir item soal diperoleh yakni dari 0,046 sampai 0,642. Berdasarkan hasil analisis nilai korelasi item 0,05 nilai lebih kecil dari nilai r tabel. Kecuali soal nomor 2 mendapatkan hasil uji validatas dengan nilai lebih besar dari $\mathrm{r}$ table. Karena koefisien korelasi soal nomor 1 sampai 10 kecuali nomor 2 nilai kurang dari $\mathrm{r}$ table maka dapat disimpulkan bahwa item -item tersebut tidak berkorelasi signifikan dengan skor total (dinyatakan tidak valid) sehingga harus dikeluarkan dan diperbaiki. Perbaikan ini dilakukan dengan uji pakar.

Lembaran angket sebelum dilakukan untuk instrumen maka di uji Prasyarat kepada 15 orang siswa diluar sampel.Hasil analisis menunjukan bahwa jumlah respondens 15 , df $=15$ maka diperoleh rtabel = 0,4821 , dan ternyata hanya item pernyataan yang valid adalah item nomor 6,7,dan 9.dan item yang lain tidak valid. Maka dapat disimpulkan bahwa item - item tersebut tidak berkorelasi signifikan dengan skor total,sehingga harus dikeluar dan diperbaiki. Perbaikan ini dilakukan dengan uji pakar.

Uji reliabilitas angket dilakukan untuk mengetahui apakah lembar angket tersebut bias digunakan sebagai instrument dalam penelitian. Data respon 15 siswa dalam penelitian itu adalah sebagai berikut: Hasil perhitungan menunjukan 0,4519 yang berarti lebih besar dari 0,05 (0,4519>0,05).maka nilainya menjadi 0,4409 .

Uji homogenitas sampel diambil dari data tes tertulis kelas kontrol dan kelas eksperimen ini dilakukan untuk mengetahui keseimbangan sampel yang sama - sama belum diberi perlakuan.

Uji homogenitas sampel kelas kontrol terhadap kelas eksperimen pada SMP ABT Kota Sorong yang belum diberi perlakuan melalui perhitungan SPSS 20 . Hasil menunjukan bahwa nilai $\alpha=0,595>0,05$ maka kedua sampel dinyatakan homogen.

Uji normalitas data sampel tes tertulis awal kelas control diperoleh output sebagai berikut:

Hasil perhitungan menunjukan bahwa nilai berdasarkan rumusan Shapiro wilk yakni 0,132 > 0,05 maka data tes tertulis kelas kontrol itu berdistribusi normal. Uji Normalitas Data Tes Tertulis Akhir Kelas Kontrol Hasil perhitungan menunjukan bahwa berdasarkan rumusan shipro wilk bahwa 0,140>0,005 maka data tes tertulis akhir kelas kontrol berdistribusi normal. Uji Normalitas Data Tes Tertulis Awal Kelas Eksperimen. Hasil perhitungan menunjukan bahwa berdasarkan rumusan shipro wilk bahwa 0,014 <0,05 maka data hasil tes ter tulis awal kelas kontrol berdistribusi tidak normal. Uji Normalitas Data Tes Tertulis Akhir kelas Eksperimen Hasil perhitungan menunjukan bahwa berdasarkan rumusan shipro wilk bahwa 0,080 >0,05 maka data tes ter tulis awal kelas kontrol berdistribusi normal.

Hasil perhitungan menunjukan bahwa 0,181 > 0,005 maka data angket tersebut memiliki sebaran normal. Analisis uji hipotesis dalam penelitian ini digunakan untuk menjawab hipotesis yang telah ditentukan. Data yang digunakan dalam analisis hipotesis ini adalah data tes tertulis awal dan data tes tertulis akhir masing - masing kelas. Teknik analisis yang digunakan adalah statistik parametrik dan non parametrik. Bila data berasal dari populasi yang berdistribusi normal, maka menggunakan analisis statistik parametrik dan bila data berasal dari populasi yang berdistribusi tidak normal maka menggunakan analisis statistik non parametrik.

Uji hipotesis dilakukan untuk kelas kontrol menggunakan uji T- 2 sampel berpasangan karena pada kelas dilakukan tes tertulis awal dan tes tertulis akhir.dan dari data tersebut mengalami distribusi normal. Maka dari data tersebut terlihat nilai t hitung yakni 0,000 < t table sebesar 2,14479 maka H1 di tolak sehingga hasilnya sama. Berdasarkan hasil uji t tersebut maka dapat disimpulkan bahwa hipotesis yang diterima yakni Hasil belajar pada tes awal terhadap tes akhir dengan metode konvensional dalam pembelajaran sistem peredaran darah manusia di SMP ABT Kota Sorong sama.

Uji hipotesis dilakukan dengan Mann Whitney. Hal ini dilakukan karena berdasarkan pengujian normalitas data tes tertulis pada kelas eksperimen sebagian mengalami distribusi tidak normal. 
Perhitungan Mann Whitney. Hasil perhitungan terlihat bahwa nilai probabilitas 0,002 maka keputusan yang diambil H1 diterima $(0,002<0.05)$ jadi H0 ditolak, H1 diterima artinya hasil belajarnya sebelum dan sesudah pada kelas kontrol dan kelas eksperimen tidak sama.

Hasil hipotesis diuji dengan menggunakan uji $\mathrm{T}$ independen test karena data uji normalitas tes akhir kontrol dan tes akhir eksperimen berdistribusi normal. Dari hasil perhitungan statistic uji T 2 berpasangan bebas antara kelas kontrol dan kelas eksperimen terlihat bahwa nilai probilitas 3,769 > 2,048 oleh karena itu maka H0 ditolak dan H1 diterima, yakni hasil pembelajaran kelas kontrol dan kelas eksperimen berbeda.

Hasil hipotesis angket kelas kontrol terhadap kelas eksperimen diuji dengan menggunakan uji $\mathrm{T}$, untuk mengetahui motivasi siswa dalam PBM. Hasil perhitungan ini mengambarkan motivasi pada kedua kelas tesebut sama ini terlihat dari t hitung $=2,456>$ 2,0484 berarti Ho ditolak, Hi diterima.

Observasi Teman Sejawat Kelas Kontrol Terhadap Kelas Eksperimen

Uji Hipotesis dari kelas kontrol terhadap kelas eksperimen tidak dihitung dengan statistik melainkan di lihat berdasarkan aspek penilaian.

\begin{tabular}{|l|l|l|}
\hline \multirow{2}{*}{ Aspek penilaian } & \multicolumn{2}{|l|}{ Skor } \\
\cline { 2 - 3 } & $\begin{array}{l}\text { kont } \\
\text { rol }\end{array}$ & $\begin{array}{l}\text { ekspe } \\
\text { rimen }\end{array}$ \\
\hline Efektif PBM & 3 & 3 \\
\hline Kerjasama siswa dalam PBM & 2 & 2 \\
\hline Interaksi guru dan siswa & 3 & 4 \\
\hline Keaktifan siswa dalam PBM & 2 & 2 \\
\hline Media mudah dipahami & 3 & 3 \\
\hline Siswa lebih mudah pahami & 3 & 3 \\
\hline Melibatkan banyak siswa & 2 & 2 \\
\hline Pelaksanaan PBM sesuai waktu & 3 & 3 \\
\hline Jumlah & 21 & 22 \\
\hline
\end{tabular}

Hasil perbandingan dari semua aspek yang diamati antara kelas kontrol dan kelas eksperimen adalah hampir sama.

Hasil uji instrument tes tertulis diperoleh fakta bahwa tingkat kesukaran soal pada tes awal dinyatakan sedang untuk butir soal tes. Sedangkan soal no 4,6,8, dinyatakan jelek. Soal yang baik adalah soal yang memiliki tingkat kesukaran sedang.

Hasil uji daya pembeda tes tertulis awal dinyatakan cukup baik. Hal ini menunjukan bahwa instrument soal dapat di gunakan untuk melihat hasil belajar siswa. Karena setiap soal mempunyai daya pembeda yang tidak sama. Hasil uji validitas dan reliabilitas soal menunjukan bahwa soal tes tertulis awal tidak valid namun reliabel.

Alat ukur yang baik harus valid dan reliabel. Reabilitas selalu menyokong validitas. Sebuah alat ukur valid harus reliabel, namun reliabel belum tentu valid. Uji pakar dilakukan untuk mengatasi butir soal yang tidak valid agar butir soal bisa dapat digunakan untuk instrument penelitian.

Hasil pengujian angket menggunakan instrument validitas dan reliabilitas. Dan dari fakta bahwa angket penelitian tidak valid dan reliabel.

Observasi teman sejawat pada penelitian ini tidak dilakukan perhitungan secara spesifik, karena observasi teman sejawat merupakan instrument pendukung pada penelitian ini. Selain lembaran observasi, instrument yang digunakan sebagai pendukung penelitian ini adalah instrument dokumentasi.

Berdasarkan hasil perhitungan uji hipotesis tes tertulis awal maupun tes tertulis akhir menunjukan bahwa prestasi belajar siswa dengan metode konvensional sebelum dan sesudah tidak ada perbedaan yang signifikan ( nilainya sama). Hal ini disebabkan karena pembelajaran masih berpusat kepada guru sebagai sumber belajar bagi mereka, sehingga kesempatan siswa untuk ikut memahami pembelajaran sangat kecil. Selain itu kemampuan komunikasi siswa dan guru juga belum terjalin secara komunikatif dan kondusif dikarenakan siswa masih takut, malu, dan memiliki kepercayaan diri yang masih rendah. Interaksi antara siswa juga masih bersifat individual. Hal tersebut sependapat dengan Johnson dan Smith dalam (14) yang menyatakan bahwa suatu model pembelajaran tradisional atau konvensional tidak terdapat adanya kerjasama untuk membangun pemahaman konsep secara bersama-sama, melainkan hanya mengandalkan kemampuan individual, kemampuan sosial tidak dikembangkan, dan tidak adanya proses berpikir bersama dalam memberikan kesimpulan akhir terhadap permasalahan yang diajukan. Hal ini sangat didukung oleh data observasi teman sejawat dikelas kontrol diperoleh fakta bahwa nilai dari item pernyataan - pernyataan tersebut rendah. Berdasarkan hasil angket diperoleh uji hipotesis hasil angket tersebut menunjukkan bahwa siswa pada kelas kontrol PBM masih berpusat paa guru.

Maka secara keseluruhan rana kognitif, afektif dan psikomotor pada kelas kontrol dapat disimpulkan tidak mengalami perubahan.

Hasil perhitungan uji hipotesis berdasarkan data instrumen tes tertulis pada kelas eksperimen

diperoleh bahwa prestasi belajar siswa sebelum dan sesudah proses pembelajaran dengan menggunakan media animasi komputer di kelas eksperimen tidak sama. Perolehan hasil belajar tersebut menunjukan bahwa penerapan model pembelajaran animasi komputer dapat merubah hasil belajar siswa dan efektifitas pembelajaran yang baik bagi siswa dalam memahami konsep pembelajaran. Hal ini dapat dibuktikan dari hasil nilai rata - rata posttest yang lebih tinggi pada kelas eksperimen dibandingkan dengan kelas kontrol dan dibuktikan dengan uji Mann whitney. Siswa lebih memfokuskan diri mereka untuk memperhatikan pembelajaran yang diberikan oleh guru, siswa mampu untuk menjawab setiap pertanyaan yang di berikan guru, dan adanya interaksi siswa dan guru sangat terlihat, ini dapat di buktikan dengan 
adanya hasil responden menjawab setuju pada item pernyataan nomor 3,4,5. Hal ini menunjukan bahwa ada respon yang baik dari siswa terhadap penerapan media animasi komputer. Hal tersebut sesuai dengan pernyataan (15) fungsi utama media pendidikan pembelajaran adalah sebagai alat bantu mengajar yang turut mempengaruhi iklim, kondisi dan lingkungan belajar yang ditata dan diciptakan oleh guru.

Observasi dikelas kontrol pembelajaran interaksi antara siswa dan guru tidak nampak, siswa cendrung lebih pasif.

Perbandingan hasil tes tertulis akhir pada kelas kontrol terhadap kelas eksperimen terlihat bahwa prestasi belajar siswa kelas kontrol masih berada dibawah kelas eksperimen. Perbandingan tes tertulis akhir dapat dilihat secara manual maupun perhitungan secara statistik. Hasil perbandingan manual dapat dilihat pada gambar grafik perbandingan tes tertulis akhir kelas kontrol terhadap kelas eksperimen yang ditampilkan pada gambar 3.1 membuktikan perolehan jumlah skor nilai yaitu 2 sampai 6 atau nilai rata - rata 3,8 sedangkan jumlah skor untuk nilai eksperimen yaitu 4 sampai 7 atau nilai rata - rata 5,9. Perbandingan berdasarkan perhitungsn statistik seperti analisis hasil data penelitian membuktikan bahwa hipotesis yang diterima yakni hasil belajar siswa dengan pembelajaran konvensional pada kelas kontrol dan hasil belajar siswa setelah perlakuan pembelajaran dengan mengunakan media animasi di kelas eksperimen tidak sama. Hal ini merupakan dampak perlakuan pembelajaran menggunakan media animasi komputer dikelas eksperimen. Media animasi komputer ini dapat memberikan pengalaman visual dalam rangka mendorong siswa untuk belajar lebih baik dan siswa mudah memahami materi yang diberikan guru. Ini sesuai dengan pendapat (16), yang menyatakan bahwa Penggunaan media dalam pembelajaran atau disebut juga pembelajaran bermedia dalam proses belajar mengajar dapat membangkitkan keinginan dan minat yang baru, membangkitkan motivasi dan rangsangan kegiatan belajar.

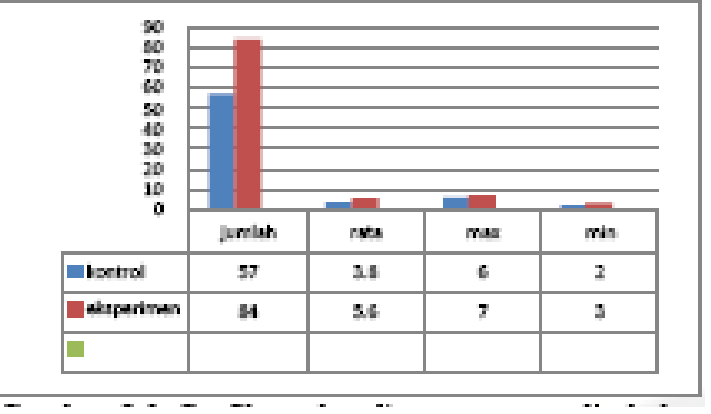

Gambar $3 . \overline{1}$ Grafik perbandingan tes tertulis kelas kontrol dan kelas eksperimen.

Hasil yang diperoleh dari data angket akhir setelah diberlakukan perlakuan yang berbeda di masing-masing kelas menyatakan motivasi belajar kelas eksperimen terhadap kelas kontrol tidak sama. Hal ini dibuktikan dengan hasil perhitungan statistik yang menunjukan hipotesis yang diterima yakni motivasi belajar siswa kelas kontrol berbeda dengan kelas eksperimen. Perbandingan ini dapat dilihat dari data yang diperoleh dan dibuat grafik yang ditampilkan pada gambar 3.2 menunjukan bahwa nilai rata - rata perbandingan grafik kelas kontrol dan kelas eksperimen tidak sama. Kondisi ini juga didukung oleh hasil observasi PBM yang dilakukan oleh teman sejawat, terlihat dengan jelas seluruh item pernyataan mempunyai skornya tidak sama. Maka secara keseluruhan media animasi baik digunakan dan dapat mempengaruhi dari rana kognitiuf .

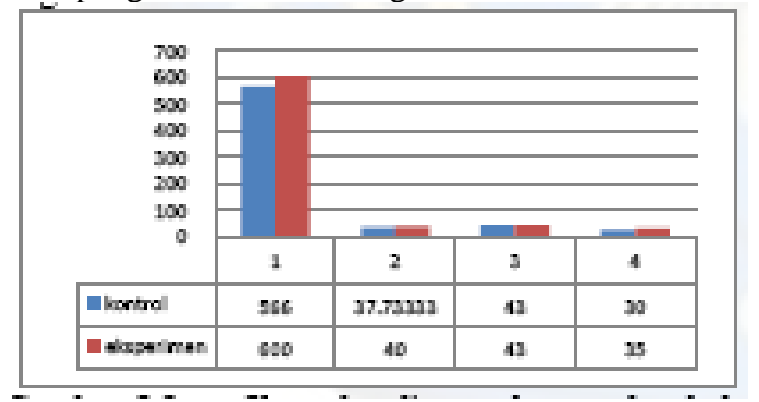

Gambar $3 . \ddot{2}$ grafik perbandingan däa angket kelas kontrol terhadap kelas eksperimen.

Berdasarkan penelitian ini maka penerapan media animasi komputer dapat berpengaruh positif pada ranah kognitif, afektif dan psikomotor.

\section{KESIMPULAN}

Berdasarkan hasil penelitian disimpulkan: 1. Hasil belajar siswa setelah menggunakan media animasi komputer lebih berpengaruh positif dibandingkan dengan hasil belajar siswa tanpa mengunakan media animasi (uji $\mathrm{T}$ independen 0,595< 2,04841). 2. Respon siswa pada kelas eksperimen lebih baik dibandingkan respon kelas kontrol (T diperoleh 0,278 < ), ini terlihat bahwa motivasi siswa dengan media animasi komputer nilai rata - rata 40, sedangkan kelas kontrol nilai rata - rata 37. 3. Observasi di kelas kontrol dan kelas eksperimen berbeda.

Secara umum kesimpulan penelitian ini tentang implementasi media animasi komputer pada materi peredaran darah manusia efektif pada ranah kognitif, afektif dan psikomotor.

\section{DAFTAR PUSTAKA}

(1) Undang-undang Republik Indonesia No 20, Tentang Sistem Pendidikan Nasional (Sisdiknas). Jakarta: Sinar Grafika. (2003)

(2) http://w.w.w.diknas.Net.

(3) Wuryastuti Sri, Inovasi Pembelajaran IPA di Sekolah Dasar, Jurnal Pendidikan dasar No 9. ( 2008)

(4) Irawan,Boby..Pengembangan Multimedia Pembelajaran Komputer: Seminar Riset Unggul Nasional Informatika dan komputer. FTI UNSA 2013

(5) Aji, Pram Satyo dan Suparman, Pengaruh Media Pembelajaran Menggunakan Macromedia Flash 8 Pokok Bahasan Internet Pada Mata Pelajaran Tik Terhadap Prestasi Belajar Siswa Kelas Xi Ipa Sma N 6 Purworejo, Jurnal Pendidikan Teknik Informatika Edisi 1 Tahun (2013) 
(6) Hasruddin, Peran Multi Media Dalam Pembelajaran Biologi Jurnal Tabularasa PPS UNIMED Vol.6 No (2009).

(7) Hakim, L. Karyanto, P. Maridi, Pengaruh MoModel Pembelajaran Problem Based Instruction Disertai Media Audio Visual Terhadap Hasil Belajar Biologi Siswa Kelas X Sma Negeri 1 Ngemplak Tahun Pelajaran 2011/2012. Biology FKIP Sebelas Maret University (2012)

(8) Yuniastuti, Euis Upaya Meningkatkan Keterampilan Proses Dan Hasil Belajar Biologi Dengan Pendekatan Pembelajaran Jelajah Alam Sekitar Pada Siswa Kelas Vii Smp Kartika V-1 Balikpapan, Jurnal Socioscientia Kopertis Wilayah Xi Kalimantan Februari, Volume 5 Nomor 1, 31. (2013).

(10) Holloway, I dan Wheeler, S, 2 nd Ed, Research in nursing, Oxford, Blackwell Science. (2002).

(11) Wicaksoni dkk.. Jurnal Internasional - Desain Penelitian Menggunakan Quasi Experiment. Program Studi Teknologi Pembelajaran Progra Pasca Sarjana Universitas Negeri Malang. (2012)

(12) Istijanto,). Aplikasi Praktis Riset Pemasaran Jakarta: Gramedia Pustaka Utama (2009)

(13) Arikunto,Suharsimi,). Dasar -Dasar Evaluasi Penelitian.Jakarta: Bumi ksara. (2006)

(13) Sugiyono,). Metodologi Penelitian Kuantitatif, Kualitatif R dan D, Bandung: Alfabet (2009)

(14) Shirle Maihoff, Teaching Techniques vol 65. No 4 Avaiabel at: ( 2008 )

(15) Azhar Arsyad,). Media Pembelajaran. Jakarta: PT Raja Grafindo Persada. (2003)

(16) A.Kosasih, Optimalisasi Media Pembelajaran, Jakarta: PT Grasindo Persada (2007) 